\title{
Rusijos kariuomenès kariai lietuviai vokiečių belaisvių stovyklose Pamaryje (Tucholèje ir Czerske) 1914-1918 metais
}

\section{Zbignevas Karpus (Zbigniew Karpus)}

Pirmojo pasaulinio karo metu ị vokiečių bei austrų-vengrų nelaisvę pateko daug Rusijos armijos kareivių. Nors nėra tikslių duomenų, manoma, kad vien ị vokiečių nelaisvę buvo patekę daugiau negu 2 milijonai caro armijos karių: ukrainiečių, lenkų, lietuvių, Vidurinès Azijos tautų atstovų ir kitų. Iki šiol ši itin įdomi ir svarbi sritis istorinejje literatūroje nebuvo išsamiau nagrinėjama. Pvz., Ukrainoje ukrainiečių belaisvių gyvenimą belaisvių stovyklose Vokietijoje, Italijoje, Lenkijoje ir Čekoslovakijoje Pirmojo pasaulinio karo metu ir vẻliau (1918-1924 m. laikotarpiu) imta tyrinèti tik prieš keletą metų. Tačiau rusai, kaip lenkai ir, manyčiau, lietuviai, šiais dalykais nesidomi. Mano manymu, šie tyrimai reikalingi, nes apima dideles karių grupes, be to, tai įmanoma padaryti, nes yra išlikusių dokumentų iš įvairių belaisvių stovyklų, irengtų teritorijose, kurios po 1918 m. ir po 1945 m. atiteko Lenkijai. Ar svarbios šios problemos ir kiek jos gali net šiuo metu turèti įtakos mūsų regiono šalių politiniams santykiams, matyti iš nuolat (nuo seno) girdimų aukščiausių Rusijos valdžios organų kaltinimų dẻl blogo elgesio su bolševikais, patekusiais ị lenkų nelaisvę.

Pirmieji rusų belaisviai ị vokiečių stovyklas po pralaimètų kovų Rytprūsiuose (1914 m. rugpjūtis-rugséjis) pateko jau 1914 m. rudenị. Tuo metu, deja, nepatikrintais Rusijos ir Vokietijos duomenimis, i nelaisvę pateko apie 135 tūkstančius caro armijos karių. Tai buvo labai didelis skaičius. Vẻlesnių metų kovos padidindavo belaisvių kiekị. Vokiečiai nesitikëjo, kad kovos Rytų fronte prasidès taip greitai ir bus tokios intensyvios. Todèl jie nebuvo pasiruošę priimti tiek belaisvių per trumpą laiką. Neturẻjo patalpų, kur būtų galima sutalpinti tiek žmonių. Reikejjo statyti naujas stovyklas. Nuo $1914 \mathrm{~m}$. rudens tai darẻ patys belaisviai. Jie dirbo sunkiomis klimato, vietos, sanitarinèmis sąlygomis, blogai maitinami. Dèl šių priežasčių daug jų mirdavo.

Rytprūsių kovų metu į nelaisvę patekusiems caro armijos kareiviams vokiečiai pirmiausia ėmè statyti stovyklas Gdansko pamaryje (vokiečių Vakarų Prūsijos provincijoje): Tucholeje, Czerske ir Gdanske. 1915 m. pra- 
džioje rusų belaisviams buvo įrengtos naujos stovyklos: Strzałkowe (galèjo gyventi apie 30 tūkst. žmonių), Szczypiorne (20 tūkst. žmonių), Bytowe bei Rytprūsiuose (Varmijos Lidzbarke ir Arys-Orzysze).

Gdansko Pamaryje, Gdansko stovykloje, maždaug 8 tūkst. rusų karininkų gyveno laivuose, prišvartuotuose prie kranto. Kitos dvi stovyklos (Tucholeje ir Czerske) buvo skirtos žemesnio rango rusų belaisviams. Pirmoji stovykla pradejjo veikti Tucholeje. Pačių belaisvių pastatytose didelèse žeminèse vienu metu galèjo gyventi apie 20 tūkst. žmonių. Stovykla užèmé maždaug 37 ha teritoriją, joje buvo antžeminių barakų ir daugiau negu 200 žeminių. Panašiai atrode ir Czersko stovykla, kurioje vienu metu galejo gyventi taip pat apie 20 tūkst. belaisvių. Manoma, kad Pirmojo pasaulinio karo metu vien Gdansko pamaryje buvo laikoma apie 40-50 tūkst. rusų belaisvių. Iš viso teritorijose, po $1918 \mathrm{~m}$. įejusiose ị atkurtos Lenkijos sudètị, vokiečių ir austrų-vengrų stovyklose buvusių belaisvių caro armijos karių - buvo daugiau negu 100 tūkst.

Rusų belaisvių gyvenimo sąlygos vokiečiu stovyklose buvo sunkios. Daug žmonių grūdosi mažame plote, o tai lėmẻ užkrečiamų ligų epidemijų protrūkius. Daug belaisvių mirè. Išlikę dokumentai rodo, kad vien dviejose Pamaryje veikusiose stovyklose (Tucholeje ir Czerske) Pirmojo pasaulinio karo metu mire 4622 rusų belaisviai (iš jų tik 15 karininkų): Tucholëje 1370 ir Czerske - 3252. Daug išlikusių belaisvių prisiminimų bei archyvinių šaltinių kalba apie sunkią belaisvių padètị vokiečių stovyklose. Kadangi karas vis tęsėsi, vokiečiai, belaisvių laimei, susidomėjo jų darbo jẻga. Todèl daug belaisvių pavieniui arba grupémis buvo perkelti dirbti į žemès ūki (dvarus) arba ị gamyklas. Dẻl to jų padėtis visais atžvilgiais pagerejo. Kartu sumažèjo belaisvių mirtingumas.

Vakarų fronte $1918 \mathrm{~m}$. lapkričio $11 \mathrm{~d}$. pasirašius paliaubas, baigėsi Pirmasis pasaulinis karas ir rusų belaisviai, buvę vokiečių stovyklose, ėmé grižti namo. Jų kelias ėjo per atgimstančios Lenkijos valstybès teritoriją. Vien 1918 m. lapkričio-1919 m. sausio ménesiais per Lenkijos teritoriją i Rytus sugrịžo apie 300 tūkst. rusų (daugiausia tai buvo belaisviai ir priverstinių darbų darbininkai).

Kaip jau minèta, istorikai, taip pat ir rusų, Pirmojo pasaulinio karo rusų belaisvių tema nesusidomėjo. Be kitų priežasčių, šią padėti galèjo lemti ir išlikusių archyvinių šaltinių būklè. Deja, nei Lenkijos, nei Vokietijos archyvuose neišliko belaisvių, laikytų ịvairiose belaisvių stovyklose, sąrašų. Jie padètų tiksliai nustatyti ị vokiečių nelaisvę patekusių karių 
skaičiu bei caro armijos karių tautybę. Be gausių belaisvių prisiminimų, išliko kai kurių stovyklų - Tucholès, Czersko ir Strzałkowo - mirusių belaisvių ir stovyklų kapinèse palaidotų asmenų sąrašai. Šiuo atžvilgiu ypač išsamūs Tucholès ir Czersko stovyklų mirusiujų belaisvių sąrašai, kurių keli egzemplioriai ir saugomi valstybės archyvuose bei vietinèse civilinės būklès aktų surašymo ịstaigose.

Išlikusios mirusiųjų knygos teikia vertingos medžiagos tyrinėjimams, jos leidžia, pvz., tirti Rusijos armijos tautinę sudètį. Tokio pobūdžio lyginamiesiems tyrinéjimams ypač naudingos tos knygos, kuriose nurodoma ne tik mirusio belaisvio gimimo data ir vieta, bet ir dalinio, kuriame jis tarnavo, numeris. Šių duomenų tyrinejjimas, ypač panaudojant naujausias kompiuterines programas, padès kiek įmanoma tiksliau nustatyti mirusių belaisvių tautybę ir dalinị, kuriame jie tarnavo. Tokie tyrinèjimai galimi ir reikia jų imtis dar ir dẻl to, kad taip nuo užmaršties išgelbètume nelaisvejje mirusius. Mirusiụjų sąrašų knygų būkle prasta, artimiausiu metu jos gali galutinai sunykti.

Kas be ko, tyrinejjimams reikia laiko ir nemažų lèšų. Problemų kyla ir dèl duomenų apie mirusius belaisvius užrašymo būdo. Rašoma buvo ranka, labai neaiškia rašysena. Užrašams perskaityti reikia laiko ir daug patirties. Vokiečių pareigūnai darydami ịrašus taip pat nesilaikè nuoseklumo. 1914-1915 m. prie belaisviu gimimo vietos nurodyta gubernija, vèliau tik bendruomenè (administracinis vienetas), kurios teritorijoje buvo tam tikra vietove. Tai sudaro papildomų sunkumų, nes reikia gerai išmanyti sudètingą Rusijos gubernijų administracini padalijimą. Neaiškumų nelieka, jeigu belaisvis buvo kilęs iš didelio miesto, pvz., Vilniaus, Kauno ar Varšuvos ir t. t.

Išanalizavus Tucholès ir Czersko stovyklų mirusių belaisvių sąrašų knygas, išaiškejjo, kad kiekvienoje iš šių stovyklų mire po kelias dešimtis caro armijos karių, gimusių Suvalkų, Kauno ir Vilniaus gubernijose (Vilniuje, Kaune, Trakų paviete). Tai belaisviai, kurių gimimo vietą lengva nustatyti. Be to, kaip minėjome, šalia daugelio mirusių belaisvių pavardžiu nurodoma tik vietove ir bendruomené. Tik tikejjimas ir pavardès skambesys rodo, kad jie galejo būti (sąlygiškai) lenkai arba lietuviai. Tolesni tyrimai leistų tiksliau nustatyti jų tautybę ir skaičių. Atsižvelgiant ị stovyklose mirusių belaisvių skaičių ir belaisvių, kilusių iš trijų minètų Rusijos gubernijų, skaičių, galima manyti, kad Pirmojo pasaulinio karo metu Tucholès ir Czersko stovyklose buvo po kelis šimtus (apie 1000) belaisvių lietuvių arba lenkų. 
Šie tyrimai Torūnèje tik prasideda. Turiu vilties, kad prie šio darbo prisijungs ir lietuviu istorikai, o tai paspartintu tyrinejjimus ir palengvintụ pastangas nustatant tikslesnị belaisvių - lietuvių ir lenkų, - mirusių ir laikytų vokiečiu nelaisvejje Pamario krašte, skaičių. Mūsų bendra istorija rodo, kad nustatyti tautybę yra labai sudètinga, todèl reikia bendrų lenkų ir lietuvių tyrinejjimų.

\section{Šaltiniai:}

Tucholès Civilinės būklès aktų surašymo ịstaigos archyvas, Dokumentai apie Tucholès stovykloje mirusius belaisvius 1914-1919 m.

Valstybès Archyvas Bydgoszcziuje:

Pamario vaivadijos valdyba Torūneje (1920-1939), Karinio laidojimų biuro pranešimai, syg.: 24276, 24277, 24283, 24289, 24312, 24313, 24317, 24357, Dokumentai, susiję su rusų belaisvių gyvenimu Tucholès ir Czersko stovyklose.

Tucholès pavieto seniūnija (1920-1939), syg.:704, Dokumentai apie Pamaryje mirusius belaisvius 1914-1921 m.

Tucholès krašto valdyba [Landratura] (1939-1945), syg.: 55, Tucholès stovykloje mirusių belaisvių sąrašai 1914-1919 m. 